\title{
Antimicrobial Compound Cladding by Successive Ionic Layer Adsorption and Reaction (SILAR) Method for Antifomite Clinical Tools
}

\author{
Shanthakumar SP*, Ivan Roberts M and George A
}

Department of Zoology, St.Josetph's College, Lang ford road, Bangalore, Karnataka, India

\begin{abstract}
Post surgical wound healing is delayed and build intricacies in many patients because of clinical fomites. Vital instruments such as catheters and surgical blades are sterilized and used with immense care by the physicians. In spite of this due to low doubling time of the microbial pathogen multiplication and colonization on the instruments is inevitable, especially in longer surgical procedures, which still remains as a challenge for the clinicians and pathologists across the world. This study regarded isolation of anti-bacterial compound from beneficial bacteria and coating the purified compound on catheters and surgical blades by successive ionic layer adsorption and reaction method to prevent the surface contamination of clinical bacterial pathogen viz., Escherichia coli. After multiple modifications optimal precursor and required timing for coating was achieved and the coated tools provided antisurface colonization property. The compound was found to have no adverse drug reaction with higher affinity human protein receptors.
\end{abstract}

Keywords: Fomite; Antibacterial coating; ADRs; Bacterial compound; Protein affinity

\section{Introduction}

Surgical site infections are a serious iatrogenesis caused by surgical fomites at large which should be culminated by finding proper solution [1]. Prevention of hospital acquired cross infection within the hospital is of a top priority as it is widely known that clinical pathogens are mostly multidrug resistant and also with high virulent factor $[2,3]$. The infection is caused by the catheters used for a longer period in dialysis procedures and in some cases permanent catheters known as permcath when contaminated spread dreadful bacteremia and peritonitis [4-6]. Post operative keratosis caused by the microkeratome blade infections were proven by many workers $[7,8]$. Affirming non infective surgical sites by specially focussing on the infections caused by the surgical blades which resulted in $80 \%$ contamination as reported in a prospective study carried out in a surgical centers [9]. Antifoul coating surgical blades with antibacterial substance would pave the way for the successful presurgical and post surgical management in mitigating the intricacies in surgical site recovery and precludes hospital acquired infections due to contaminated fomites [10]

Infectious bacterial pathogens like Achromobacter xylosoxidans [11], Staphylococcus aureus [12], Pseudomonas aeruginosa [13], Salmonella typhimurium [14], Escherichia coli [13], Shigella flexneri and Klebsiella pneumonia [15] are gram negative bacterial pathogens which are potential threat posing secondary infection to the patients across the healthcare facilities. Recent approaches in bioprospecting new antibacterial small molecules and compounds from plants, bacteria, fungi etc. against the above mentioned pathogens have been proven to have antimicrobial activity $[16,17]$. Bacteria mediated infections on the surgical tools and implants were subjected for experiment with bactericidal substance coating such as antibiotic-loaded silk fibroin/ hyaluronic acid polyelectrolyte [18], titanium based on nanoporous silica and silver nanoparticles [19,20] gentamicin-loaded coating against $S$. aureus [21], layer by layer antibacterial polysaccharide-based coatings [22] immobilization and release of bactericidal substances such as metal derivatives and polyammonium salts were used as antibiotic coating [23] and application of furanones to screen pathogenic bacterial biofilm formation on the surfaces [24] was reported.
Thin film layering of the various molecules and quantum dots on the metals and successfully sensitising them using the successive ionic layer adsorption and reaction (SILAR) method [25-27] was studied recently in various metallurgic and chemical departments. But utilisation of this technique for the medical purpose is not substantial. Hence this present study focus on (1) isolation of anti-bacterial compound dipropylS-propyl ester (C4) from bacteria Exiguobacterium mexicanum (2) thin layer coating of the antibacterial compound on the catheters and surgical blades using the successive ionic layer adsorption and reaction method. (3) Bacterial colonisation evaluation of the coated materials. (4) Adverse drug reaction and affinity interactome.

\section{Materials and Methods}

\section{Bacterial source and compound isolation}

The clinical bacterial pathogens Escherichia coli strain ATCC 25922. The beneficial bacterium Exiguobacterium mexicanum (GenBank Ac No: KF471138) was isolated and from rhizosphere soil. $48 \mathrm{~h}$ culture filtrate of E. mexicanum was prepared and separated with the ethyl acetate in separating funnel individually in the ratio of 1:1 (v/v) followed by shaking for $30 \mathrm{~min}$ in a separating funnel. The extraction was repeated thrice and the solvents with the fractions were pooled and evaporated under vacuum using a rotary evaporator (Buchi type, Switzerland). The concentrated crude extract was mixed with chloroform-silica gel slurry and loaded onto a silica gel 60-120 mesh (E-Merck, Darmstadt, Germany) column, packed in ethyl acetate:

${ }^{*}$ Corresponding author: Dr. Shanthakumar SP, Assistant Professor, Department of Zoology, St.Joseph's College, Lang ford road, Bangalore, Karnataka, India, Tel: +919941639941; E-mail: spshanthakumar@gmail.com

Received November 24, 2015; Accepted December 21, 2015; Published December 31, 2015

Citation: Shanthakumar SP, Ivan Roberts M, George A (2016) Antimicrobial Compound Cladding by Successive lonic Layer Adsorption and Reaction (SILAR) Method for Antifomite Clinical Tools. J Antimicro 1: 105. doi: 10.4172/24721212.1000105

Copyright: (C) 2015 Shanthakumar SP, et al. This is an open-access article distributed under the terms of the Creative Commons Attribution License, which permits unrestricted use, distribution, and reproduction in any medium, provided the original author and source are credited. 
chloroform: acetic acid (5:4:1) as the solvent system (the dimension of the column was $450 \times 30 \mathrm{~mm}$ ). One hundred tubes of 10 milliliters of the fractions were collected and analyzed by TLC. Fractions showing similar spots with the same $R_{\mathrm{f}}$ values were pooled and concentrated by a speed-Vac under low pressure with an evaporating temperature of $40^{\circ} \mathrm{C}$.

\section{Characterization of the metabolite}

The purified fractions were subjected to HPLC (on the bondapak column with a flow rate $1.5 \mathrm{ml} / \mathrm{min}$ and pressure up to $300 \mathrm{psi}$ ) using acetonitrile $(9: 1)$ as elutant to obtain the pure sample. The single fraction, which eluted was evaporated to dryness and subjected to Fourier Transform Infra-Red (FTIR). Infrared spectral data were measured on Perkin-Elmer 1600 series FTIR Spectrometer (Nujol, KBr disks). To determine the molecular weight, the samples were subjected to Electro Spray Ionization quadrupole Mass Spectrometry (ESIMS) Finnigan LCQ MS Detector. Source conditions were set as follows: Voltage $5 \mathrm{KV}$ : nitrogen sheath gas pressure 60 psi: heated capillary temperature $200^{\circ} \mathrm{C}$ : full scan 50 to $2000 \mathrm{~m} / \mathrm{z} \cdot{ }^{13} \mathrm{C}-\mathrm{NMR}$ and ${ }^{1} \mathrm{H}-\mathrm{NMR}$ spectra were recorded on a Bruker $300 \mathrm{MHz}$ instrument using Tetra Methyl Silane (TMS) as the internal standard. Optical density was estimated using UV spectrometry (Shimadzu) Using the spectral data of FTIR, ESIMS, ${ }^{1} \mathrm{H}-\mathrm{NMR},{ }^{13} \mathrm{C}-\mathrm{NMR}$ and UV spectrum the structure of the active principles was determined.

\section{Thin film compound layering by SILAR method}

Successive ionic layer adsorption and reaction (SILAR) method was modified after [28,29]. The surgical blades (Surgeon - no: 23) and catheters (Dispovan) were immersed in $40 \%$ of compound $\mathrm{C} 4$ at $75^{\circ} \mathrm{C}$ for 15 minutes which acted as a precursor later dipped in deionised water for 15 minutes and followed by 15 minutes (S2) cation wash which was prepared by dissolving $0.16 \mathrm{M} \mathrm{Na}_{2} \mathrm{~S}$ in deionised water. The cycle was repeated 20 times.

\section{Antimicrobial analysis}

Coated surgical blades and catheters using procedure mentioned above was analysed for coating properties on surgical blades only as the needles cannot be subjected for testing under atomic force microscopyAFM (NTEGRA; NT-MDT, Moscow, Russia). Antibacterial activity of $\mathrm{C} 4$ coated and uncoated blades and catheters (negative control) were tested on an nutrient agar (NA) plate spread with $1 \mu \mathrm{L}$ of $0.2 \mathrm{OD}_{600}$, surgical blades and catheters were incubated three replication batch for $1 \mathrm{hr}, 2 \mathrm{hr}$ and $3 \mathrm{hr}$ per batch at $37^{\circ} \mathrm{C}$. After incubation the coated and uncoated instruments were introduced into sterile nutrient broth and $\mathrm{OD}_{600}$ bacterial growth was recorded and parallely plated on NA to estimate the $\mathrm{CFU} / \mathrm{ml}$ to verify bacterial surface colonisation.

\section{Adverse drug reaction (ADRs) analysis}

The off-target adverse drug reaction on humans protein was screened using the insilico tool named DRAR-CPI [30].

\section{Data analysis}

All the parameters were replicated five times and activity data were subjected to Duncan multiple range test (DMRT) to draw relative statistical differences among the treatment using the SPSS 16.0 version (Statistical package social sciences, USA). Results at $P<0.05$ were considered to be statistically significant.

\section{Results}

\section{Bactericidal coating and antisurface colonising activity}

Thin film coating of the compound was confirmed with AFM thickness record of $2.9 \mu \mathrm{m}$ (Figure 1) with surface roughness average of $0.071 \mu \mathrm{m}$. The compound $\mathrm{C} 4$ had demonstrated significant antimicrobial and antisurface colonisation activity against the bacterial pathogens tested. Among the three incubation time there were no bacterial colonisation found in first two hours incubation of both coated catheters and surgical blades and the uncoated instruments have shown the bacterial colonisation with $3.5 \pm 0.2 \mathrm{cfu} / \mathrm{ml}$ after $1 \mathrm{hr}$ incubation, $3.5 \pm 0.3 \mathrm{cfu} / \mathrm{ml}$ after $2 \mathrm{hr}$ incubation and $4.5 \pm 0.5 \mathrm{cfu} /$ $\mathrm{ml}$ after $3 \mathrm{hr}$ incubation in case of uncoated surgical blades (Figures 2 and 3$)$. Whereas the uncoated catheters with $0.5 \pm 0.3 \mathrm{cfu} / \mathrm{ml}$ after $1 \mathrm{hr}$ incubation, $1.5 \pm 0.3 \mathrm{cfu} / \mathrm{ml}$ after $2 \mathrm{hr}$ incubation and $1.5 \pm 0.5$ $\mathrm{cfu} / \mathrm{ml}$ after $3 \mathrm{hr}$ incubation. Even though the coated materials did not show any surface colonisation for first two hours of incubation time both surgical blades $(1.0 \pm 0.1 \mathrm{cfu} / \mathrm{ml}$ in first wash and $0.5 \pm 0.1 \mathrm{cfu} /$ $\mathrm{ml}$ in second wash) and catheter $(0.3 \pm 0.1 \mathrm{cfu} / \mathrm{ml}$ in both wash) have developed comparatively less bacterial colonisation.

\section{Compound identification}

Based on the polyphasic chemical characterization the compound C4 is identified as Dipropyl-S-propyl ester and its chemical structure was derived based on results of multi-technique analysis as follows, the RT value for compound was 3.0 in single peak in HPLC and the UV spectrometer reading for the compound 4 was $231 \mathrm{~nm}$. FTIR values of compound 4 shows following clear peaks between the range of 1700 1750 which implies presence of Carbamic acid, Ester and Carbonyl $(\mathrm{C}=\mathrm{O})$ stretch, 1050-1200 confirms presence of thiocarbamic group with $(\mathrm{C}=\mathrm{S})$ stretch, $1600-1680$ denoting $(\mathrm{C}-\mathrm{N})$ stretch, peaks between 2800-3000 range depicting alkane $(\mathrm{C}-\mathrm{H})$ stretch, 1350-1480 gives alkane $(\mathrm{C}-\mathrm{H})$ bending, The $\mathrm{H}^{1} \mathrm{NMR}\left(200 \mathrm{MHZ} \mathrm{CDCl}_{3}\right.$ ) spectrum of 0.9-1.5 depicts the presence of hydrogen in propyl group. The $\mathrm{C}^{13}$ NMR spectrum showed a peak at range between 170-185 confirms the presence of carbon in acid and ester $(\mathrm{C}=\mathrm{O}), 10-15$ confirms carbon in propyl $\left(\mathrm{R} \mathrm{CH}_{3}\right)$ group, 16-25 indicates presence of carbon in alkane $\left(\mathrm{R}_{2} \mathrm{CH}_{3}\right)$ and the molecular mass was estimated at $\mathrm{M} / \mathrm{z} 203$ by mass spectroscopy confirmed the composition $\mathrm{C}_{10} \mathrm{H}_{21}$ NOS for dipropyl-Spropyl ester.

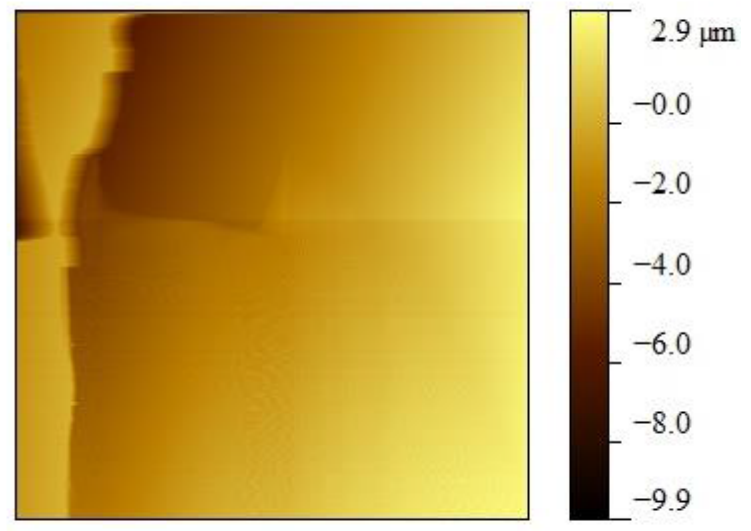

Figure 1: Atomic Force Microscopy profile showing deposit compound thickness on surgical blade. 


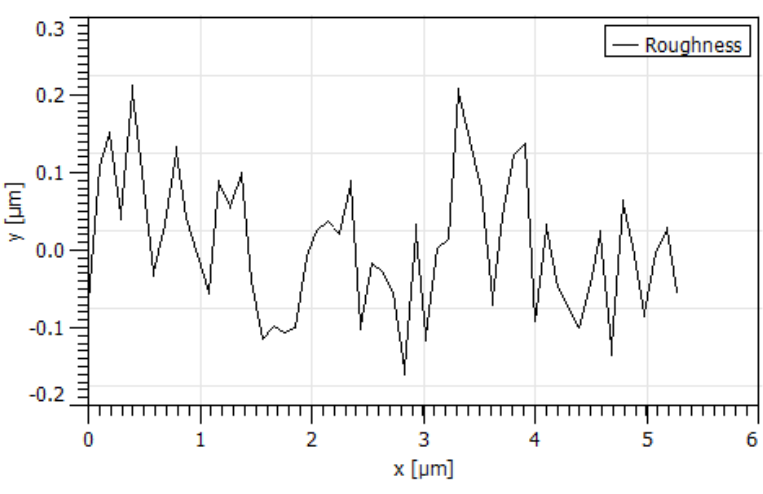

Figure 2: Roughness scale of the surgical blade substrate surface.

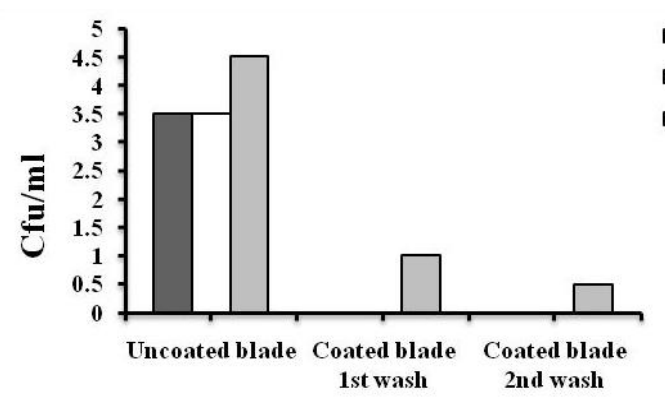

Anticolonisation assay -Surgical blade

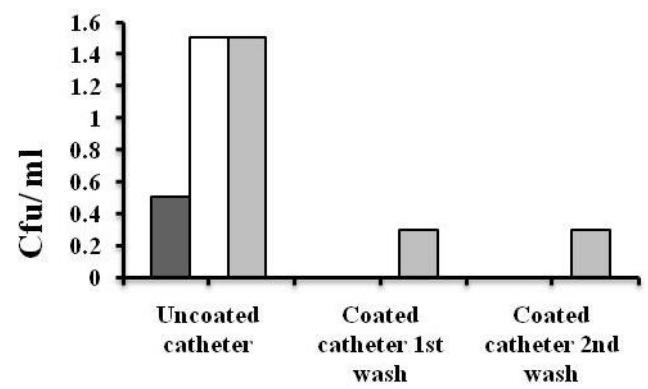

Anticolonisation assay - Catheter

Figure 3: Antimicrobial activity of compound C4 against $E$ coli.

\section{Adverse drug reaction and affinity interactome}

Putative target function of the important protein interactome inferred no adverse drug reaction and were presented according to the highest affinity (Figure 3) based on the docking score and -Z'-score for following human proteins 1 . Aldose reductase which catalyzes the $\mathrm{NADPH}$-dependent reduction of a wide variety of carbonyl-containing compounds to their corresponding alcohols with a broad range of catalytic efficiencies. -44.1354 and -2.36354 (Figure 4 ).

2. Voltage-gated potassium channel sub unit beta-2 is an accessory potassium channel protein which modulates the activity of the poreforming alpha subunit. -43.5778 and -2.15928 .

3. Ubiquitin carboxyl-terminal hydrolase 14 which is proteasome-

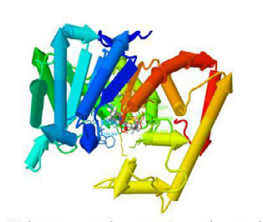

Voltage-gated potassium channe
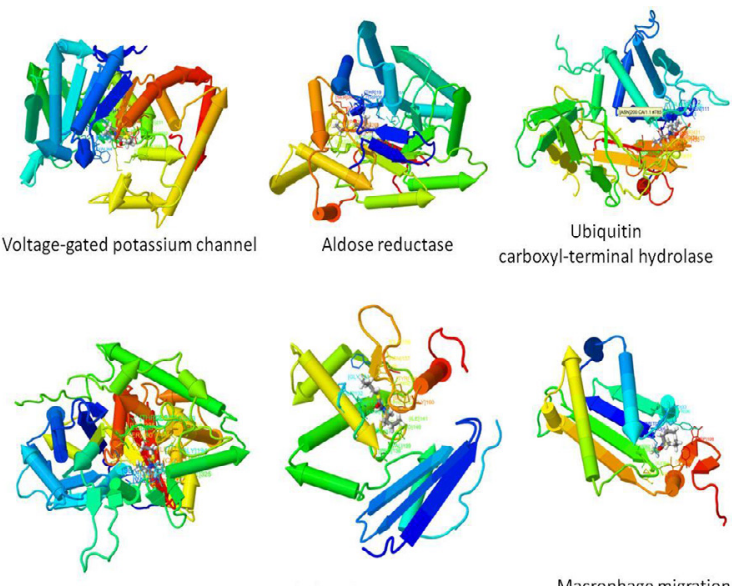

carboxyl-terminal hydrolase

Acetyl-CoAacetyltransferase
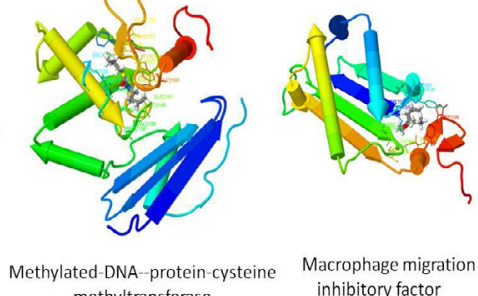

methyltransferase

Figure 4: Interaction of compound C4 with higher affinity human protein receptors.

associated deubiquitinase which releases ubiquitin from the proteasome targeted ubiquitinated proteins. Ensures the regeneration of ubiquitin at the proteasome. Is a reversibly associated subunit of the proteasome and a large fraction of proteasome-free protein exists within the cell. It is required for the degradation of the chemokine receptor CXCR4 which is critical for CXCL12-induced cell chemotaxis. Serves also as a physiological inhibitor of endoplasmic reticulum-associated degradation (ERAD) under the non-stressed condition by inhibiting the degradation of unfolded endoplasmic reticulum proteins via interaction with ERN1. Indispensable for synaptic development and function at neuromuscular junctions (NMJs). $\quad-40.4508 \quad$ and $-2.29679$

4. Acetyl-CoA acetyltransferase, mitochondrial which plays a major role in ketone body metabolism is with -39.6597 and -2.82362 .

5. Methylated-DNA--protein-cysteine methyltransferase Involved in the cellular defense against the biological effects of O6methylguanine (O6-MeG) in DNA. Repairs alkylatedguanine in DNA by stoichiometrically transferring the alkyl groupat the O-6 position to a cysteine residue in the enzyme. This is a suicide reaction: the enzyme is irreversibly inactivated. $-\mathbf{- 3 7 . 2 5 3 3}$ and -1.62553 .

6. Macrophage migration inhibitory factor. Involved in the innate immune response to bacterial pathogens. The expression of MIF at sites of inflammation suggests a role as mediator in regulating the function of macrophages in host defense. Counteracts the anti-inflammatory activity of glucocorticoids. $\quad-35.7365$ and -1.33086 .

\section{Discussion}

Recent findings on the surface contamination of surgical equipments which potentially transmits the infectious pathogens within the clinical facilities. About 66 bacterial pathogens were isolated from 44 surgical equipment's with 0 to 296 colony-forming units predominantly grampositive cocci [31]. During surgical procedures, the instruments will penetrate the skin or the external layer before reaching the actual point of contact which facilitates these pathogenic transfer from the external surface to inside and spreads infection. In case of dental tools sterilization can be tedious due their micro structure and complex architecture like it is in dental burs and endodontic files [32]. 
Prevention of infection caused by the vascular catheters across the clinical procedures is felt very important by the physicians after witnessing the bacterial sepsis in patients [33-35]. Need for coating the antibacterial substance on the surgical tools to prevent the infections was illustrated by many researchers [36]. In the present study, we report the optimal surface coating methodology of the compound dipropylS-propyl ester and its antisurface colonising property against clinically important bacteria pathogens E. coli. Similar work was described earlier to prevent the surface bacterial surface colonisation by coating the clinical tools with plasma-sprayed silver-doped hydroxyapatite [37] which have proven resistance against the bacterial adhesion. Recently to curtail the implant associated infection, work related to biolfilm prevention on the medical oriented material surfaces is being carried out with the different types of nanoparticles [38] which was found to be active against Enterobacter sp. and Pseudomonas sp.

Instead of using the more toxic metallic substance for bactericidal coating, we have used bioactive compound isolated from the beneficial bacterium E. mexicanum in the present study. Many metabolites produced by the microbial agents which could be used as antibacterial materials such as siderophores, bacteriocines, lysosomes, proteases and organic acids are present in natural ecosystems. But there are no significant quantity of novel antibiotic discovery in recent past in correspondence with the evolving pathogenic strains. This is because of various challenges in the antibacterial drug discovery [39,40]. There were no major class of antimicrobials discovered between 1962 to 2000 $[41,42]$ to combat the drug resistant pathogens. Only improved version of the available drugs were registered and released instead of screening for novel drugs which could prevent adverse drug reaction.

Adverse drug reaction is the major cause of deaths and economic burden in many developed countries which spends $15 \%$ to $20 \%$ of the hospital budget to treat ADRs [43,44]. About 408 ADR cases were recorded in South India in 12 month studies and most of the cases were rated to be preventable [45]. These can be prevented by using recent pharmacokinetics and insilico analytics $[46,47]$. The possible human protein affinity studies on the isolated compound dipropyl-S-propyl ester taken up in the present studies has shown its highest interaction potential with aldose reductase with highest docking score of -44.1354 and lowest score was found in macrophage migration inhibitory factor with -35.7365 docking score. All the intermediates were also evaluated and found no adverse drug reaction according to insilico analysis [4859].

\section{Conclusion}

In recent past the technical advancement has increased the rate of the surgical procedures in saving lives. As many long duration surgical procedures were done in a shorter period, nowadays people's acceptance level to comply with surgeries instead of undergoing long term medication is higher. Along with this kind of clinical progress, there is also a demerit of cross infection because of the surgical tools. From the present study antifouling coating with dipropyl-S-propyl ester is a novel technique that had effective resistance against the clinical pathogens. This study suggests that the compounds isolated and coated may be potentially used by the clinical tool manufacturing industries to develop antifouling devices against bacterial pathogens.

\section{Acknowledgements}

Laboratory facilities provided by Principal, St.Joseph's College. Bangalore to carry out this project is highly acknowledged. The author wish to thank Dr.Michael rajamathy and Mr. Jeffery for their help in microscopy studies.

\section{References}

1. Ibrahimi OA, Sharon V, Eisen DB (2011) Surgical-site infections and routes of bacterial transfer: which ones are most plausible? Dermatol Surg 37: 17091720.

2. Gottesman MM, Fojo T, Bates SE (2002) Multidrug resistance in cancer: role of ATP-dependent transporters. Nat Rev Cancer 2: 48-58.

3. Reilman E, Hagting JG, Flipsen T, Ulmer H, van Dijl JM (2015) Towards an antimicrobial 'microglove'. Sci Rep 5: 16679.

4. Ahmed MS, Nistal C, Jayan R, Kuduvalli M, Anijeet HK (2009) Achromobacter xylosoxidans, an emerging pathogen in catheter-related infection in dialysis population causing prosthetic valve endocarditis: a case report and review of literature. Clin Nephrol 71: 350-354.

5. Rafael AE, Keshavamurthy S, Sepulveda E, Miranda CC, Okamoto T, et al. (2014) Intracardiac abscess with cutaneous fistula secondary to ventricular septal defect repair simulating sternal wound infection. Tex Heart Inst J 41 : 324-326.

6. Cankaya E, Keles M, Gulcan E, Uyanik A, Uyanik H (2014) A rare cause of peritoneal dialysis-related peritonitis: Achromobacter denitrificans. Perit Dial In 34: 135-137.

7. Janum S, Zingg W, Classen V, Afshari A (2013) Bench-to-bedside review: Challenges of diagnosis, care and prevention of central catheter-related bloodstream infections in children. Crit Care 17: 238.

8. Betjes MG (2011) Prevention of catheter-related bloodstream infection in patients on hemodialysis. Nat Rev Nephrol 7: 257-265.

9. Pang CJ, Wang LY, Sun ST, Han L, Li X (2012) Zhonghua Yan Ke Za Zhi 48 394-397.

10. Khan AM, Larson B, Noth J, Rosen R, Bouchard C (2008) Microbial cultures of the microkeratome blade immediately after flap construction in laser in situ keratomileusis. J Cataract Refract Surg 34: 842-845.

11. Oliveira AC, Gama CS (2015) Evaluation of adherence to measures for the prevention of surgical site infections by the surgical team. Rev Esc Enferm USP 49: 767-774.

12. Lambadi PR, Sharma TK, Kumar P, Vasnani $P$, Thalluri SM, et al. (2015) Facile biofunctionalization of silver nanoparticles for enhanced antibacterial properties, endotoxin removal, and biofilm control. Int J Nanomedicine 10 2155-2171.

13. Patel PK, von Keudell A, Moroder P, Appleton P, Wigmore R, et al. (2015) Recurrent Septic Arthritis Due to Achromobacter xylosoxidans in a Patient With Granulomatosis With Polyangiitis. Open Forum Infect Dis 2: ofv145.

14. Bode LG, Rijen MM, Wertheim HF, Vandenbroucke-Grauls CM, Troelstra A, et al. (2015) Ann Surg 10

15. Negi V, Pal S, Juyal D, Sharma MK, Sharma N (2015) Bacteriological Profile of Surgical Site Infections and Their Antibiogram: A Study From Resource Constrained Rural Setting of Uttarakhand State, India. J Clin Diagn Res 9 : DC17-20.

16. Humeera N, Kamili AN, Bandh SA, Amin SU, Lone BA, et al. (2013) Antimicrobial and antioxidant activities of alcoholic extracts of Rumex dentatus L. Microb Pathog 57: 17-20.

17. Shanthakumar SP, Duraisamy P, Vishwanath G, Selvanesan BC, Ramara $V$, et al. (2015) Broad spectrum antimicrobial compounds from the bacterium Exiguobacterium mexicanum MSSRFS9. Microbiol Res 178: 59-65.

18. Chaftar N, Girardot M, Labanowski J (2015) Comparative evaluation of the antimicrobial activity of 19 essential oils. Adv Exp Med Biol

19. Samrot AV, Prasad RJ, Rio AJ, Sneha SJ (2015) Bioprospecting of Brevibacillus brevis Isolated from Soil. Recent Pat Biotechnol 9: 42-49.

20. Friedman M, Buick R, Elliott CT (2006) Antimicrobial activities of plant compounds against antibiotic-resistant Micrococcus luteus. Int $\mathrm{J}$ Antimicrob Agents 28: 156-158

21. Arpaçay P, Türkan U (2015) Development of antibiotic-loaded silk fibroin hyaluronic acid polyelectrolyte film coated CoCrMo alloy. Biomed Tech (Berl).

22. Massa MA, Covarrubias C, Bittner M, Fuentevilla IA, Capetillo P, et al. (2014) 
Citation: Shanthakumar SP, Ivan Roberts M, George A (2015) Antimicrobial Compound Cladding by Successive lonic Layer Adsorption and Reaction (SILAR) Method for Antifomite Clinical Tools. J Antimicro 1: 105. doi: 10.4172/2472-1212.1000105

Page 5 of 5

Synthesis of new antibacterial composite coating for titanium based on highly ordered nanoporous silica and silver nanoparticles. Mater Sci Eng C Mater Biol Appl 45: 146-153.

23. Zhao L, Chu PK, Zhang Y, Wu Z (2009) Antibacterial coatings on titanium implants. J Biomed Mater Res B Appl Biomater 91: 470-480.

24. Li LL, Wang LM, Xu Y, Lv LX (2012) Preparation of gentamicin-loaded electrospun coating on titanium implants and a study of their properties in vitro. Arch Orthop Trauma Surg 132: 897-903.

25. Junter GA, Thebault P, Lebrun L (2015) Acta Biomater 7: 30187-30182.

26. Glinel K, Thebault P, Humblot V, Pradier CM, Jouenne T (2012) Antibacteria surfaces developed from bio-inspired approaches. Acta Biomater 8: 1670-1684

27. Lönn-Stensrud J, Landin MA, Benneche T, Petersen FC, Scheie AA (2009) Furanones, potential agents for preventing Staphylococcus epidermidis biofilm infections? J Antimicrob Chemother 63: 309-316.

28. Huang JX, Bishop-Hurley SL, Cooper MA (2012) Development of anti-infectives using phage display: biological agents against bacteria, viruses, and parasites. Antimicrob Agents Chemother 56: 4569-4582.

29. Stowe SD, Richards JJ, Tucker AT, Thompson R, Melander C, et al. (2011) Antibiofilm compounds derived from marine sponges. Mar Drugs 9: 2010-2035.

30. de Lima Pimenta A, Chiaradia-Delatorre LD, Mascarello A, de Oliveira KA Leal PC, et al. (2013) Synthetic organic compounds with potential for bacterial biofilm inhibition, a path for the identification of compounds interfering with quorum sensing. Int J Antimicrob Agents 42: 519-523.

31. Chudobova D, Nejdl L, Gumulec J, Krystofova O, Rodrigo MA, et al. (2013) Complexes of silver(I) ions and silver phosphate nanoparticles with hyaluronic acid and/or chitosan as promising antimicrobial agents for vascular grafts. Int $J$ Mol Sci 14: 13592-13614

32. Raafat D, Sahl HG (2009) Chitosan and its antimicrobial potential--a critical literature survey. Microb Biotechnol 2: 186-201.

33. Taglietti A, Diaz Fernandez YA, Amato E, Cucca L, Dacarro G, et al. (2012) Antibacterial activity of glutathione-coated silver nanoparticles against Gram positive and Gram negative bacteria. Langmuir 28: 8140-8148.

34. Ruden S, Hilpert K, Berditsch M, Wadhwani P, Ulrich AS (2009) Synergistic interaction between silver nanoparticles and membrane-permeabilizing antimicrobial peptides. Antimicrob Agents Chemother 53: 3538-3540.

35. Schindler M, Osborn MJ (1979) Interaction of divalent cations and polymyxin B with lipopolysaccharide. Biochemistry 18: 4425-4430.

36. Shengyuan Y, Nair AS, Ramakrishna S (2015) Morphology of the Electrospun TiO2 on the Photovoltaic Properties of CdS Quantum Dot-Sensitized Solar Cells. J Nanosci Nanotechnol 15: 721-725.

37. Zhang Z, Tang Y, Liu C, Wan L (2014) Fabrication of In2S3 nanoparticle decorated $\mathrm{TiO} 2$ nanotube arrays by successive ionic layer adsorption and reaction technique and their photocatalytic application. J Nanosci Nanotechnol 14: 4170-4177.

38. Zhang X, Liu J, Johansson EM (2015) Efficient charge-carrier extraction from Agâ,,S quantum dots prepared by the SILAR method for utilization of multiple exciton generation. Nanoscale 7: 1454-1462

39. Lee H, Wang M, Chen P, Gamelin DR, Zakeeruddin SM, et al. (2009) Efficient CdSe quantum dot-sensitized solar cells prepared by an improved successive ionic layer adsorption and reaction process. Nano Lett 9: 4221-4227.
40. Deshpande NG, Sagade AA, Gudage YG, Lokhande CD, Sharma R (2007) Journal of Alloys and Compounds 436: 421-426.

41. Ziebarth NM, Dias J, Hürmeriç V, Shousha MA, Yau CB, et al. (2013) Quality of corneal lamellar cuts quantified using atomic force microscopy. J Cataract Refract Surg 39: 110-117.

42. Luo H, Chen J, Shi L, Mikailov M, Zhu H, et al. (2011) Nucleic Acids Res 39: 10

43. Saito Y, Kobayashi H, Uetera Y, Yasuhara H, Kajiura T, et al. (2014) Microbia contamination of surgical instruments used for laparotomy. Am J Infect Contro 42: 43-47.

44. Kumar KV, Kiran Kumar KS, Supreetha S, Raghu KN, Veerabhadrappa AC, et al. (2015) Pathological evaluation for sterilization of routinely used prosthodontic and endodontic instruments. J Int Soc Prev Community Dent 5: 232-236.

45. Panknin HT (2015) Kinderkrankenschwester 34: 5-7.

46. Hoppe B (1995) Central venous catheter-related infections: pathogenesis predictors, and prevention. Heart Lung 24: 333-339.

47. Dumont C, Nesselrodt D (2012) Preventing central line-associated bloodstream infections CLABSI. Nursing 42: 41-46.

48. Fielding GA, Roy M, Bandyopadhyay A, Bose S (2012) Antibacterial and biological characteristics of silver containing and strontium doped plasma sprayed hydroxyapatite coatings. Acta Biomater 8: 3144-3152.

49. Roy M, Fielding GA, Beyenal H, Bandyopadhyay A, Bose S (2012) Mechanical, in vitro antimicrobial, and biological properties of plasma-sprayed silver-doped hydroxyapatite coating. ACS Appl Mater Interfaces 4: 1341-1349.

50. Brennan SA, Fhoghlu C Ni, Devitt BM, O’Mahony FJ, Brabazon D, et al. (2015) 33336.

51. Silver LL (2011) Challenges of antibacterial discovery. Clin Microbiol Rev 24 71-109.

52. Pucci MJ, Bush K (2013) Investigational antimicrobial agents of 2013. Clin Microbiol Rev 26: 792-821.

53. Fischbach MA, Walsh CT (2009) Antibiotics for emerging pathogens. Science 325: 1089-1093

54. Walsh C (2003) Where will new antibiotics come from? Nat Rev Microbiol 1 65-70.

55. Qing-ping S, Xiao-dong J, Feng D, Yan L, Mei-ling Y, et al. (2014) Consequences measurement, and evaluation of the costs associated with adverse drug reactions among hospitalized patients in China. BMC Health Serv Res 14: 73.

56. Wu C, Bell CM, Wodchis WP (2012) Incidence and economic burden of adverse drug reactions among elderly patients in Ontario emergency departments: a retrospective study. Drug Saf 35: 769-781.

57. Jose J, Rao PG (2006) Pattern of adverse drug reactions notified by spontaneous reporting in an Indian tertiary care teaching hospital. Pharmacol Res 54: 226-233.

58. Ishikawa T, Sakurai A, Hirano H, Lezhava A, Sakurai M, et al. (2010) Emerging new technologies in Pharmacogenomics: rapid SNP detection, molecula dynamic simulation, and QSAR analysis methods to validate clinically important genetic variants of human ABC Transporter ABCB1 (P-gp/MDR1). Pharmacol Ther 126: 69-81.

59. Chatman LA, Morton D, Johnson TO, Anway SD (2009) A strategy for risk management of drug-induced phospholipidosis. Toxicol Pathol 37: 997-1005. 